\title{
The Cellular Dust Hypothesis and The Laws of Thermodynamics
}

\author{
Seun Ayoade* \\ Independent Resesarcher, Nigeria
}

*Corresponding author: Seun Ayoade, BSc (Hons), Independent Resesarcher, Winner 2004 NIIT Scholarship (Grade A++), Nigeria

\section{Opinion}

The cellular dust hypothesis states that all life (including human life) and the physical universe/entire cosmos came to be as a result of the activities/chemical reactions carried out by indestructible microscopic (maximum size 500 nanometre) entities called microzymas [1]. Discovered in the mid-1800s, alternative terms for macerozymes include cellular dust, protits, bions, scintillating corpuscles, siphonospora polymorpha etc [2]. These microzymas are found in all living things and continue to exist when living things perish. They are immortal and are considered to be the basic unit of life/living thing according to the Terrain and Germ Terrain Duality theories of disease [3]. Microzyma have also been proposed to be linked to dark energy/ dark matter [4]. Most scientists continue to deny the existence of the microzymas. The first law of thermodynamics states that energy can neither be created nor destroyed. It can only change forms. In any process, the total energy of the universe remains the same [5]. Compare this first law of thermodynamics to the following statements- 'There is nothing but what ought to be-Galileo 'Nothing is created, nothing is lost'-Lavoisier Nothing is the prey of death: all things are the prey of life [6] 'The microzymian theory of the living organism is true because it agrees at the same time with these conceptions and with the three aphorisms which I have chosen for epigraph to this first part of my preface
a) Nothing is but what ought to be
b) Nothing is created, nothing is lost
c) Nothing is the prey of death; all things are the prey of life [7]

"The microzyma is at the beginning and at the end of every living organization. It is the fundamental anatomical element whereby the cellules, the tissues, the organs, the whole, of an organism are constituted living" [8] The living being, filled with microzymas, carries in himself the elements essential for life, for disease, for death and for destruction. And that this variety in results may not too much surprise us, the processes are the same. Our cellules, it is a matter of constant observation, are being continually destroyed by means of a fermentation very analogous to that which follows death. Penetrating into the heart of these phenomena we might really say, were it not for the offensiveness of the expression, that we are constantly rotting [9]. The second law of thermodynamics states that the entropy (measure of disorder) of an isolated system not in equilibrium will tend to increase over time. The creation of cells, tissues, organs and systems by the coordinated activity of microzymas and the deterioration and eventual death of the cells, tissues and organs subsequent to the deco-ordination of the microzymas is reminiscent of the second thermodynamics law of entropy. The second and third laws of thermodynamics in their nitty-gritty essence are similar to and reminiscent of the microzyman concept. Entropy too supports the theory that cellular dust could theoretically be the creators/designers/originators of life and the universe. In summary these laws of science suggest that the microzyma theory of origins/cellular dust hypothesis is theoretically possible.

\section{References}

1. Seun A (2018) A New Origin of Life and the Universe ProposedMicrozymian. Peer Re J Foren \& Gen Sci 1(5).

2. Mister SA (2017) Koch's Postulates and Germ Terrain Dualism; Cellular Dust as Yet another Term for Microzymas. JOJ Nurse Health Care 5(4): 555666 .

3. Mister Seun Ayoade (2017) The Differences Between the Germ Theory, the Terrain Theory and the Germ Terrrain Duality Theory. JOJ Nurse Health Care. 4(2): 555631. 
4. Seun A (2018) Could Microzymas be the Elusive Dark Matter? Could Microzymas be the Force Behind Dark Energy? Peer Re J Foren \& Gen Sci 1(5).

5. http://physicsforidiots.com/physics/thermodynamics/

6. (1912) A Bechamp Blood and Its Third Anatomical Element. Kessinger Legacy printers.
7. Ibid, p. 32.

8. Ibid, pp. 205.

9. Ibid, pp. 240. (c) (1)

This work is licensed under Creative Commons Attribution 4.0 License

To Submit Your Article Click Here: Submit Article

DOI: $10.32474 /$ GJAPM.2019.01.000110

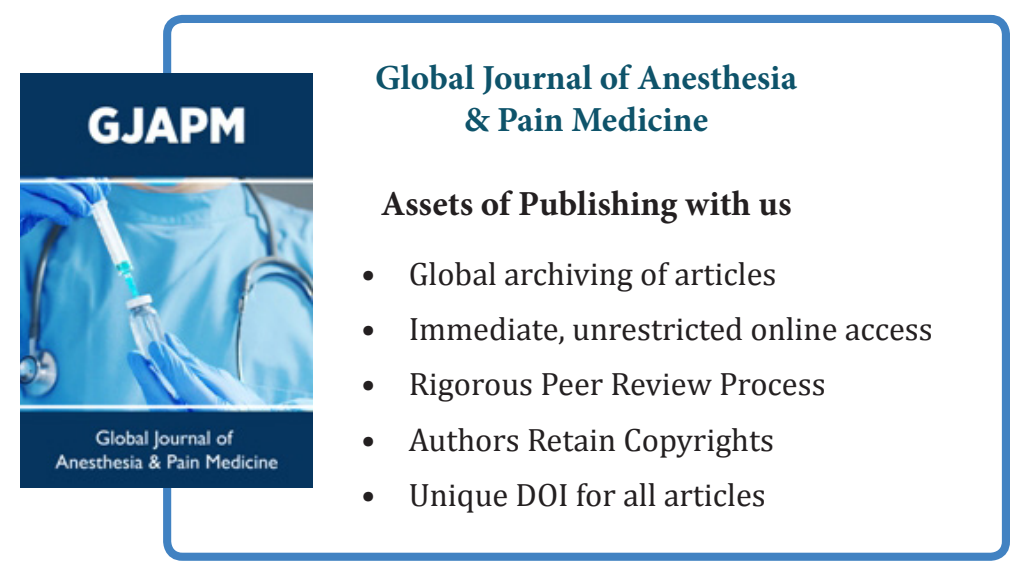

